\title{
Lacking in abundance: undernutrition in a Peri-urban fishing community in Coastal Ghana
}

\author{
Delia Akosua Bandoh*, Abubakar Manu² and Ernest Kenu
}

\begin{abstract}
Background: Malnutrition is a major problem in the world, especially in developing countries such as Ghana. Malnutrition is directly and indirectly responsible for over a million deaths in under-fives worldwide. In spite of the abundance of protein from fish and other staples in fishing communities, they are not spared of the problem of undernutrition. The study sought to assess the prevalence undernutrition among children under-five years in a fishing community in Ghana.

Methods: We conducted a community-based cross-sectional study in Ekumfi Narkwa. We assessed the nutritional status of 250 children aged 6-59 months using anthropometric methods. A structured questionnaire was also used to gather socio-demographic data on the children. We generated nutritional indices with Microsoft Excel 2010 and WHO Anthro software version 3.2.2. We generate frequencies and percentages and ran a simple logistic regression to determine factors associated with malnutrition using STATA software version 13.
\end{abstract}

Results: About 80\%(198/250) of the children were reported to have consumed fish products more than three times in the past week whiles $85 \%(214 / 250)$ consumed staples more than three times in the past week. More than one-quarter (26.4\%) of the children were under-nourished. The prevalence of stunting, wasting and underweight were 17.6\% (44/250), $4.4 \%(11 / 250)$ and $12 \%(30 / 250)$ respectively. Age of caregiver was found to be associated with a child being underweight. The age group of the caregiver was found to be associated with undernutrition (OR:1.53; 95\%Cl:1.07-219).

Conclusions: These findings suggest a high prevalence of under-five undernutrition in the fishing community in spite of the abundance of fish and its presence in their diet. Malnutrition interventions should therefore be extended to these communities. These interventions in fishing communities need to be tailored towards caregiver utilization of fish and other food sources available in order to improve nutrition of the children.

Keywords: Fishing community, Undernutrition, Diet, Stunting, Underweight, Wasting, Under-five

\section{Background}

Malnutrition is one of the major public health concerns worldwide with developing countries facing the greatest burden [1-3]. Its consequences include retarded physical and mental growth and even death [4]. In developing countries, such as Ghana, undernutrition is the major type of malnutrition people struggle with. Each year, $35 \%$ of the deaths of children under-five is attributed to undernutrition $[2,5]$.

\footnotetext{
*Correspondence: deliabandoh@st.ug.edu.gh

${ }^{1}$ Ghana Field Epidemiology and Laboratory Training Programme, School of

Public Health, University of Ghana, Accra, Ghana

Full list of author information is available at the end of the article
}

According to UNICEF, there has been a $37 \%$ drop in undernutrition, precisely low-height-for-age (stunting) worldwide since 1990 [6]. However, an evaluation of child malnutrition trends over the years points out that the decline in the rate of stunting has been slow. Therefore, millions of children still have low chances of survival if the current trends continue [7]. de Onis and his colleagues had earlier observed an uneven progress in the trend of improved malnutrition. From their observation, Africa showed very little improvement compared to Eastern and South-Eastern Asia [8]. Thus, there is the need for new ways of tackling the malnutrition in Africa

(C) The Author(s). 2018 Open Access This article is distributed under the terms of the Creative Commons Attribution 4.0 International License (http://creativecommons.org/licenses/by/4.0/), which permits unrestricted use, distribution, and 
to be looked into to help eradicate the problem and save millions of innocent lives.

One way of saving these lives is by improving their nutritional status through addition of nutritious foods such as fish to their diet. Fish serves as a major source of protein for many under developed countries. This is because, it is rich in proteins, essential fatty acids and micronutrients [9].

Fishing communities are characterized by the presence of fish and high consumption because of its abundance. Also, it has been recognized that household fish involvement can contribute to improving their nutritional status [10].

However, in spite of the abundance of fish in fishing communities and its presence contributing to their nutritional status, people living in fishing communities are generally thought to be at a high risk of malnutrition $[11,12]$. This is because, in most of these fishing communities, fish is sold more often and not consumed by the household. Many fishing communities in developing countries of Africa and Asia are characterized by food insecurity and poverty [11].

Ghana has a wide coastline which contributes about 3. $9 \%$ of the national gross domestic product (GDP) through the fishing activities and also provides part of the nation's protein source through fish [13]. Thus, there is the need to assess the existing situation in fishing communities in Ghana to help tackle the problem of malnutrition. This would improve their health and nutritional status which is of great essence to the nation because of their significant contribution.

Assessing the nutritional status of children under five years, serves as a sensitive indicator of the overall health of the community $[14,15]$, thus a good tool to find out the health status of under-fives and the community as a whole.

The study sought to assess the prevalence of undernutrition among children under five years in Ekumfi Narkwa, a fishing community in the Central Region using anthropometric methods.

\section{Methods}

\section{Study setting}

Ekumfi Narkwa is located along the coastline of the Central region. It is one of the nine fishing communities in the district. It has a population of 4169 with 506 children under-five [16]. The community has a Community based Health Planning and Services (CHPS) compound with health workers residing in the facility. The major economic activity in the community is fishing and selling of the fresh or smoked fish. Every year, during the lean fishing season, most of the fishermen migrate to the Western region of the country to continue their fishing activities. Their wives and children go along with them to facilitate the handling and selling of the fish.

\section{Sample size}

The sample size was determined with the following assumptions: confidence interval of $95 \%$, a proportion of $20.2 \%$ for children under five in the Central region who are undernourished. This proportion is according to the 2014 Ghana Demographic and Health Survey [17]. The total of 250 caregiver and child pairs consented, and were recruited.

\section{Sampling method}

We selected respondents from all the suburbs in the community namely Asemasa- Esikado, Ahenbrom, Kokodo and Adukrom. Respondents were selected proportionate to the size of the suburb. In each suburb, at least forty-five (45) respondents were selected. The proportions selected from each suburb were; Ahembrom (35\%), Adukrom (25\%), Esikado-Asemasa (22\%) and Kokodo (18\%). This was used because the community had no proper housing list [18]. Sampling of respondents from their households was done by the modified random walk method.

In the modified random walk, we identified and listed key land marks in each suburb. These included the taxi rank, clinic outreach points, schools, churches, information center, mosque, and CHPS compound. In each suburb, a listed landmark was randomly selected as the starting point for sampling of respondents. Field workers identified the house closest to the landmark and started selection of respondents from there. They continued in a clockwise manner till the sample size for the suburb was met. This procedure was repeated in each suburb till the total sample size was obtained.

In each house, we asked for caregivers with children under-five years. Every household in each sampled house with a child aged 6-59 months was given the opportunity to be part of the study. In places where a household had more than one child under five, names of both children were written on pieces of paper and the mother randomly selected one. The selected child was taken as part of the study.

The study was explained to the caregivers of these children and they were taken through the consent procedure. Caregivers who agreed signed the informed consent document before the questionnaire was administered and measurements of the child taken. In cases were the mother was less than 18 years, permission was sort form her guardian to allow her take part in the study. Again, we ensured that the guardian was present during the consent procedure and all her questions were answered. Both the mother and her guardian signed before the interviews were conducted. Participation in the study was voluntary and based on caregiver's willingness to give full consent and the availability of the child during the study period. 


\section{Data collection}

Data was collected by interview administered questionnaires. Research assistants interviewed mothers and caregivers on their demographic characteristics, general practices, the major food groups the child had eaten in the past week and also took the child's anthropometric measurements. Interviews and anthropometric measurements were done in the home of the caregiver.

General practices were defined as the community's accepted way of doing things. General practices assessed were; those normally involved in childcare (who acts as caregivers), and nature of economic activities the community engages in (type of activity, nature of activity).

For the assessment of major food groups the underfive had eaten, caregivers recalled the number of times in the week the child had eaten staples (cereals, roots, tubers and plantain) and the number of times the child had taken fish products. The instrument used for food recall was adopted from the Food and Nutrition Technical Assistance (FANTA) project [19].

\section{Anthropometric measurements}

Anthropometric measures (weight and height) were taken twice with a calibrated infantometer, ShorrBoard brand, Weigh and Measure, LLC brand and weighing scale, Seca 803 brand respectively. All measurements were recorded. All children were clothed in only underwear or light clothing during measurements. The measurements were taken using WHO standard procedure [20].

Each measurement was taken by two skilled field workers who had been trained in taking various anthropometric measurements of children under five years.

\section{Data analysis}

Data was entered in Microsoft Excel Office 2010, cleaned and exported to STATA Software, Texas, USA, version 13 for analysis. Data collected on demographic characteristics and their general practices were presented in tables as frequencies and percentages. Means were calculated for weight and height in Microsoft Excel and were exported to WHO ANTHRO software for calculation of the nutritional indices; Height-for-age, (HA), Weight-for-age (WA) and Weight-for-Height (WH)) and their respective Z-scores. The nutritional status was assessed by the three commonly used indicators of nutritional status; height for age, weight for height and weight for age [16]. According to the WHO, child whose height for age, weight for height or weight Z-scores fell below -2 of the mean standard deviation of the Z-score of the population was classified as stunted, wasted or underweight respectively [21]. The overall nutritional status was also determined as those whose who had Z-scores below -2 of the population mean for any of the three nutritional indices assessed.
The anthropometric data was presented by age and sex since growth failure varies from age to age and within sexes. Age was categorized in months as: 6-11, $12-17,18-23,24-35,36-47$, and 48-59 respectively.

A simple logistic regression was run to assess the significant association between the nutritional status of the under-fives and the various factors assessed. Significant association was determined at $95 \%$ confidence interval and $p$-value $<0.05$.

\section{Results}

\section{Background characteristics of respondents}

A total of 250 children between the ages of 6-59 months with their caregivers in Ekumfi Narkwa were assessed. Majority of the caregivers, $96.4 \%$ (241/250) were mothers. The average age of the caregivers interviewed was $28.7 \pm 9.5$ years. The youngest mother was 15 years and the oldest, 45 years. Most of the caregivers were between the ages of 20-25 years $(37.6 \%, 94 / 250)$. The modal level of education was junior high school. The main occupation was trading of non-fish products, 55. $2 \%(138 / 250)$ (Table 1).

Of the two hundred and fifty respondents, $79.2 \%$ consumed fish more than three times in the past week,

\begin{tabular}{|c|c|}
\hline Variable & Frequency $(\%) N=250$ \\
\hline \multicolumn{2}{|l|}{ Age of caregiver (years) } \\
\hline Below 20 & $17(6.8)$ \\
\hline $20-25$ & 94(37.6) \\
\hline $26-30$ & 48(19.2) \\
\hline $31-35$ & $47(18.8)$ \\
\hline 36 and above & $44(17.6)$ \\
\hline \multicolumn{2}{|l|}{ Level of education of caregiver } \\
\hline No formal education & $76(30.4)$ \\
\hline Primary & $67(26.8)$ \\
\hline Junior high & 97(38.8) \\
\hline Senior high & $8(3.2)$ \\
\hline Tertiary & $2(0.8)$ \\
\hline \multicolumn{2}{|l|}{ Primary occupation } \\
\hline Unemployed & 29(11.6) \\
\hline Fishmonger & $35(14.0)$ \\
\hline Farmer & $15(6.0)$ \\
\hline Trader(other than fish products) & 138(55.2) \\
\hline Artisan & 28(11.2) \\
\hline Other occupations & $5(2.0)$ \\
\hline \multicolumn{2}{|l|}{ Migration status } \\
\hline Permanent resident & 154(61.6) \\
\hline Migrant & 96(38.4) \\
\hline
\end{tabular}


whiles $85.6 \%$ consumed staples more than three times in the past week (Table 2).

Half of the children surveyed were males, 50.4\% (126/ 250 ). The median age group was $24-35$ months (187/ 250). The mean age of the children was 27 months with the highest number recruited being within the ages of $12-23$ months. Table 3 shows the distribution of underfives by age and sex.

\section{Nutritional status of under-fives}

Total undernourished children were seen to follow the same growth pattern as underweight. The highest percentage was seen in children between the ages of 12-23 months. Stunting was the most common form of undernutrition whiles wasting was the least common (Fig. 1).

From Table 4, almost 18\% (44/250) of the children were stunted, $12 \%(30 / 250)$ underweight and 4\% (10/ 250) wasted. The mean Z-score (standard deviation) for the population from the reference group for each of the anthropometric indices were $-1.1,-0.9$ and -0.4 for height-for-age, weight-for-age and weight-for-age respectively.

From Table 5, Children between the age group 24-35 months had the highest level of stunting, 26.3\% (17/72) whiles those within the range of 6-11 months had the lowest percentage of stunting (5\%). For underweight, children within the ages of 12-23 months had the highest percentage, $19.2 \%$ (15/78) and the children between 6 and 11 months again had the lowest percentage of underweight (5.7\%) that is only 2 out of the 37 children were underweight. Just 1 of the 39 children between the ages of 36-47 months was wasted. However, two of the 24 children (8.3\%) between 48 and 60 months were wasted. A higher percentage of boys were stunted compared to their female counterparts (boys-19.2\% (24/ $125)$, girls- $16.1 \%(20 / 125))$. However, more females were wasted than the males.

The age of the caregiver was found to be significantly associated with being underweight (OR:1.53; 95\%CI:1. 07-219). The other demographic characteristics assessed were also not found to be associated with nutritional status of the under-fives (Table 6).

Table 2 Food take by Under-Fives over the past week in Ekumfi Narkwa

\begin{tabular}{lll}
\hline Food group & \multicolumn{2}{l}{ Frequency of food groups taken } \\
\cline { 2 - 3 } & More than 3 times & Less than 3 times \\
\hline Fish and sea foods & $198(79.2)$ & $52(20.8)$ \\
Staples & $214(85.6)$ & $36(14.4)$ \\
Vitamin A rich vegetables & $84(33.6)$ & $166(66.4)$ \\
Other vegetables & $126(50.4)$ & $124(49.6)$ \\
\hline
\end{tabular}

Table 3 Distribution of Under-Fives in Ekumfi Narkwa by Age and Sex

\begin{tabular}{llll}
\hline Age group (months) & \multicolumn{2}{l}{ Sex Frequency (\%) } & Total \\
\cline { 2 - 3 } & Female & Male & \\
\hline $6-11$ & $23(62.2)$ & $14(37.8)$ & $37(14.8)$ \\
$12-23$ & $30(38.5)$ & $48(61.5)$ & $78(31.2)$ \\
$24-35$ & $35(48.6)$ & $37(51.4)$ & $72(28.8)$ \\
$36-47$ & $22(56.4)$ & $17(43.6)$ & $39(15.6)$ \\
$48-59$ & $14(58.3)$ & $10(41.7)$ & $24(9.6)$ \\
Total & 124 & 126 & 250 \\
\hline
\end{tabular}

\section{Discussion}

The prevalence of undernutrition among under-fives was assessed in Ekumfi Narkwa, a fishing community along the coastline of Ghana. From the assessment, 26. $4 \%(66 / 250)$ were under-nourished. The prevalence of stunting, underweight and wasting was $17.6 \%, 12 \%$ and $4.4 \%$ respectively. The prevalence for stunting and wasting obtained from this study were lower than the Ghana Demographic and Health Survey (GDHS) 2014 report. According to the GDHS, the prevalence of stunting and wasting among under-fives in Ghana are 19\% and $5 \%$ respectively. However, the rate of underweight was slightly higher $(12 \%)$ than the national prevalence of $11 \%$ found by the 2014 Ghana Demographic and Health Survey [17].

According to the WHO classification for severity of malnutrition, the prevalence of stunting and wasting in Ekumfi Narkwa are classified as low severity of malnutrition whiles the prevalence of underweight in the community is medium severity of malnutrition [21].

The indicator weight-for-age can be used as an overall indication of a population's nutritional health [20]. Thus, it could be implied that about $12 \%$ of the community are not nutritionally healthy. Lack of good nutrition can

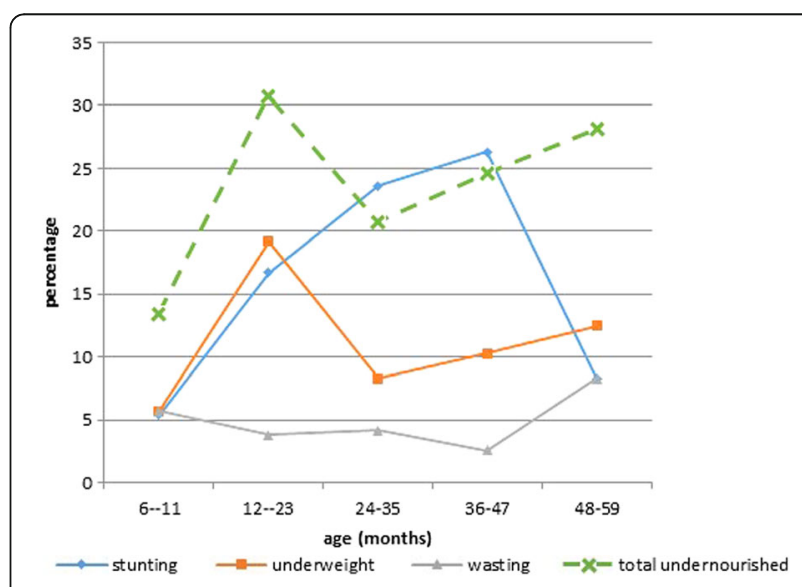

Fig. 1 Undernutrition by age and sex 
Table 4 Prevalence of Undernutrition among Under-fives in Ekumfi Narkwa

\begin{tabular}{|c|c|c|c|c|}
\hline \multirow[b]{2}{*}{ Category } & \multicolumn{3}{|c|}{ Anthropometric Indices } & \multirow{2}{*}{$\begin{array}{l}\text { Overall } \\
\text { nutritiona } \\
\text { status }\end{array}$} \\
\hline & Height-for-age (\%) & Weight-for-age (\%) & Weight-for-height (\%) & \\
\hline Low (below - 2 SD) & $44(17.6)$ & $30(12.0)$ & $11(4.4)$ & $66(26.4)$ \\
\hline Normal (Above - 2 SD) & $206(82.4)$ & $220(88.0)$ & $239(95.6)$ & $184(73.6)$ \\
\hline Total & $250(100)$ & $250(100)$ & $250(100)$ & $250(100)$ \\
\hline
\end{tabular}

lead to low productivity and inability of people to reach they maximum potential.

Stunting reflects the cumulative effects of undernutrition and infections. This indicator also reflects long term chronic restriction of a child's growth potential. [3, 21, 22]. We observed that the prevalence of stunting was lower in the first year of life but increased through 12-35 months. This is in similar to earlier works done by Jayatissa and Badake [23, 24]. They attribute this pattern to poor weaning and complementary feeding practices leading to inadequate protein and energy intake in the child [24]. The caregiver's lack of knowledge about proper infant and young feeding practices in spite of the abundance of the required food nutrients the child needs such as protein from fish can eventually lead to stunting of the child.

No significant differences were seen in the levels of stunting and the ages of the children $(p<0.05)$. This finding is contrary that of a study in Kenya where older children were more likely to be severely stunted as compared to younger children [25]. Since stunting is sign of prolonged lack of good nutrition, older children who have been exposed to poor nutrition for a longer period of time are more likely to be stunted than younger children.

In our study, the age of the caregiver was found to be associated with being underweight. Older mothers were 0.53 less likely to have underweight children compare to younger mothers. A study on maternal age and child nutrition also reviewed younger mothers have a higher chance of having undernourished children compared to older ones [26]. This could be due to the fact that younger mothers may lack experience and might not have been exposed to nutrition education or other nutrition interventions that may exist in the community.

The level of undernutrition in under-fives in the community, was higher than expected since there was a constant abundance of protein and energy giving foods. Again, a study in Ghana on dietary diversity in a fishing community revealed that there is an abundance of animal protein in especially from sea food and staples in their diet [27].

This finding of high level of undernutrition could be attributed to a number of reasons including the following. Most of the caregivers were traders involved in nonfish product trade. Thus, though may be an abundant commodity, there is a possibility they might not have time to obtain the food sources needed to provide meals that would meet their children's nutrient needs. In addition to this, since a considerable number of them are migrants, they might not be able to get enough food to meet their children's nutrient needs.

The underlying reason for the high prevalence of undernutrition could be lack knowledge on good infant and young child nutrition practices. Most caregivers might not know how the abundance of fish and other

Table 5 Categorisation of Undernutrition among Under-fives by Age Group and Sex Distribution in Ekumfi Narkwa

\begin{tabular}{|c|c|c|c|c|c|c|}
\hline \multicolumn{7}{|c|}{$\mathrm{N}=250$ Frequency (\%) } \\
\hline \multirow[t]{2}{*}{ Factors } & \multicolumn{2}{|l|}{$\mathrm{HAZ}$} & \multicolumn{2}{|l|}{ WAZ } & \multicolumn{2}{|l|}{$\mathrm{WHZ}$} \\
\hline & Stunted & Normal & Underweight & Normal & Wasted & Normal \\
\hline \multicolumn{7}{|c|}{ Age (months) } \\
\hline $6-11$ & $2(5.4)$ & 35 (94.6) & $2(5.4)$ & 35 (94.6) & $2(5.4)$ & $35(94.6)$ \\
\hline $12-23$ & $13(16.7)$ & $65(83.3)$ & $15(19.2)$ & $63(80.8)$ & $3(3.8)$ & $75(96.2)$ \\
\hline $24-35$ & $17(23.6)$ & $55(76.4)$ & $6(8.3)$ & $66(91.7)$ & $3(4.2)$ & $69(85.8)$ \\
\hline $36-47$ & $10(25.6)$ & $29(74.4)$ & $4(10.3)$ & $35(89.7)$ & $1(2.6)$ & $38(97.4)$ \\
\hline $48-59$ & $2(8.3)$ & $22(91.7)$ & $3(12.5)$ & $21(87.5)$ & $2(8.3)$ & $22(91.6)$ \\
\hline \multicolumn{7}{|l|}{ Sex } \\
\hline Male & $24(19.0)$ & $102(80.9)$ & $17(13.5)$ & $109(87.5)$ & $3(2.4)$ & $123(97.6)$ \\
\hline Female & $20(16.1)$ & $104(83.8)$ & $13(10.5)$ & $111(89.5)$ & $8(6.4)$ & $116(93.5)$ \\
\hline Total & $44(17.6)$ & $206(82.4)$ & $30(12.0)$ & $220(88.0)$ & $11(4.4)$ & $239(95.6)$ \\
\hline
\end{tabular}

HAZ height-for-age z-score, WAZ weight-for-age z-score, WHZ weight-for-height z-score 
Table 6 Association between demographic characteristics and anthropometric indices assessed

\begin{tabular}{|c|c|c|c|c|c|c|}
\hline \multirow[t]{2}{*}{ Factors } & \multicolumn{2}{|l|}{ Stunting } & \multicolumn{2}{|l|}{ Underweight } & \multicolumn{2}{|l|}{ Wasting } \\
\hline & $\begin{array}{l}\text { Crude OR } \\
(95 \% \mathrm{Cl})\end{array}$ & $\begin{array}{l}\text { Adjusted OR } \\
(95 \% \mathrm{Cl})\end{array}$ & $\begin{array}{l}\text { Crude OR } \\
(95 \% \mathrm{Cl})\end{array}$ & $\begin{array}{l}\text { Adjusted OR } \\
(95 \% \mathrm{Cl})\end{array}$ & $\begin{array}{l}\text { Crude OR } \\
(95 \% \mathrm{Cl})\end{array}$ & $\begin{array}{l}\text { Adjusted OR } \\
(95 \% \mathrm{Cl})\end{array}$ \\
\hline Caregiver age group & $1.00(0.77-1.31)$ & $1.05(0.83-1.38)$ & $1.45^{*}(1.03-2.04)$ & $1.53^{*}(1.07-2.19)$ & $1.17(0.69-1.20)$ & $1.29(0.76-2.20)$ \\
\hline Caregiver's Occupation & $1.02(0.79-1.33)$ & $1.01(0.78-1.32)$ & $0.65^{*}(0.44-0.94)$ & $0.60(0.962-2.42)$ & $0.71(0.40-1.25)$ & $0.68(0.37-1.23)$ \\
\hline Caregiver's education & $1.23(0.87-1.77)$ & $1.23(0.85-1.77)$ & $1.26(0.83-1.92)$ & $1.53(0.96-2.42)$ & $1.23(0.64-2.40)$ & $1.39(0.69-2.80)$ \\
\hline Child's sex & No observation & & No observation & & No observation & \\
\hline Child's age & $0.85(0.64-1.11)$ & $1.11(0.82-1.51)$ & $1.03(0.75-1.43)$ & $1.02(0.73-1.43)$ & $0.94(0.57-1.57)$ & $0.90(0.50-1.62)$ \\
\hline
\end{tabular}

*Significant at $p<0.05$

food sources available could be used to improving the nutritional status and health of the children. Education on appropriate infant feeding practices is key to solving the community's challenge. Again, this finding could also be an indication that, the abundance of a single food commodity or food group (such as fish) required for adequate growth may not enough to improve nutritional status. According to Steyn and colleagues, a variety of food groups are required to meet the nutritional needs of the child [28]. Consumption of foods from all the essential food groups and other factors such the environment, the health of the child all contribute to the nutritional status of the child. Better child, maternal and environmental practices need to be adopted to improve young child care, growth and development and also the nutritional status of the children and the community as a whole.

This study had some limitations which include some of the following. This was a cross-sectional study thus, it was difficult to examine any potential temporal relationships or causal associations between dependent and independent variables. Furthers studies on how seasonal changes affect the nutritional status of fishing communities and the factors associated with it would be very beneficial in understanding these relationships.

\section{Conclusion}

This study revealed that almost one-third of the children under-fives in Ekumfi Narkwa were undernourished though protein from sea foods is a stable part of their diet. This finding suggests that some fishing communities in Ghana are faced with the problem of malnutrition in spite of the abundance of protein from sea foods. This can mainly be attributed to lack of knowledge required to make good use of food sources in abundance. Malnutrition interventions mainly education on improvement of child nutrition using available food sources should be increased in these communities.

\section{Abbreviations}

GDHS: Ghana Demographic and Health Survey; GDP: Gross domestic product; GHS: Ghana Health Service; HA: Height - for - Age; HAZ: Height - for - Age Z Score; WA: Weight - for - Age; WAZ: Weight - for - Age Z - Score; WHO: World Health Organization

\section{Acknowledgements \\ I would like to acknowledge the Ekumfi District Health Directorate and the Ekumfi Narkwa CHPS Compound for their help and support during data collection.}

Funding

The study was funded by the authors of this paper.

\section{Availability of data and materials}

The dataset used for analysis during the current study are available from the corresponding author on reasonable request.

\section{Authors' contributions}

$\mathrm{DAB}$ - conceptualized the study, wrote the proposal, did data acquisition, performed analyses and drafted the manuscript. AM - reviewed the proposal, drafted the manuscript and made intellectual inputs into the final manuscript. EK - conceptualized the study, reviewed the proposal, performed analyses, drafted the manuscript and made intellectual inputs. All authors read and approved the manuscript.

\section{Ethics approval and consent to participate}

Ethical clearance was given by the Ghana Health Service Ethical Review Board (ID NO: GHS-ERC: 47/02/15). Permission was given by the Health Directorates at the regional and district levels. Community entry was done and the study was explained to the community and its leaders. A written informed consent which explained the confidentiality, voluntary participation, withdrawal and risk/ benefits of the study was administered to respondents and those who agreed signed this form. In cases were the mother was less than 16 years, permission was sort form her guardian to allow her take part in the study. Again, we ensured that the guardian was present during the consent procedure and all her questions were answered. Both the mother and her guardian signed before the interviews were conducted.

\section{Competing interests}

The authors declare that they have no competing interests.

\section{Publisher's Note}

Springer Nature remains neutral with regard to jurisdictional claims in published maps and institutional affiliations.

\section{Author details}

${ }^{1}$ Ghana Field Epidemiology and Laboratory Training Programme, School of Public Health, University of Ghana, Accra, Ghana. ${ }^{2}$ School of Public Health, University of Ghana, Accra, Ghana.

Received: 14 January 2018 Accepted: 18 April 2018

Published online: 02 May 2018

\section{References}

1. Devkota SC, De A, Sathian B. Nutritional Deficiencies: Major Public Health Problem in Nepal. Am J Public Health Res. 2015;3(4A):1-5. https://doi.org/10. 12691/AJPHR-3-4A-1

2. Akorede QJ, Abiola OM. Assessment of nutritional status of under five children in Akure south local government, Ondo State. IJRRAS. 2013;14:671-81. 
3. Bain LE, Awah PK, Geraldine N, Kindong NP, Sigal Y, Bernard N, Tanjeko AT Malnutrition in sub-Saharan Africa: burden, causes and prospects. Pan Afr Med J. 2013;15:120. https://doi.org/10.11604/pamj.2013.15.120.2535

4. Nyangasa MA. Nutrition status of Ghanaian women with young childrendietary intake, anthropometric and life style data [masters]. Hamburg: Hamburg University of Applied Sciences; 2011.

5. Singer P, Ansett S, Sagoe-Moses I. What could infant and young child nutrition learn from sweatshops? BMC Public Health. 2011;11(1):276.

6. UNICEF. Every child counts. New York: United Nations Children's Fund; 2014 January 2014. Report No.: 9789280647310.

7. United Nations Children's Fund-World Health Organization- The World Bank. Child Malnutrition. Geneva: WHO; 2012. Retrieved from: http://www.who.int/ nutgrowthdb/jme_unicef_who_wb.pdf. Date: July 15, 2016

8. de Onis M, Blössner M, Borghi E, Morris R, Frongillo EA. Methodology for estimating regional and global trends of child malnutrition. Int J Epidemiol. 2004;33:1260-70.

9. Kawarazuka N. The contribution of fish intake, aquaculture, and small-scale fisheries to improving nutrition: A literature review. The World Fish Center Working Paper No.2106. Penang: The World Fish Center; 2010. p. 51.

10. Aiga H, Matsuoka S, Kuroiwa C, Yamamoto S. Malnutrition among children in rural Malawian fish-farming households. Trans R Soc Trop Med Hyg. 2009:103:827-33.

11. Beveridge MCM, Thilsted SH, Phillips MJ, Metian M, Troell M, Hall SJ. Meeting the food and nutrition needs of the poor: the role of fish and the opportunities and challenges emerging from the rise of aquaculture. J Fish Biol. 2013;83:1067-84. https://doi.org/10.1111/jfb.12187.

12. Baker-french SR. Food security and nutritional status in fishing communities in Bolivia's northern Amazon. 2013.

13. Bank of Ghana Research Department. The Fishing Sub-Sector And Ghana's Economy. Accra: Bank of Ghana, Accra; 2008.

14. World Food Programme and Center for Disease Control and Prevention. Measuring and Interpreting Malnutrition and Mortality. Rome: World Food Programme; 2005. Retrieved: http://www.unhcr.org/45f6abc92.pdf. Accessed 15 Dec 2017.

15. Amosu AM, Degun AM, Atulomah NOSband Olanrewju MF. A study of the nutritional status of Under-5 children of low-income earners in a southwestern Nigerian community. Curr Res J Biol Sci. 2011;3:578-85.

16. Ghana Statistical Service (GSS), Ghana Health Service(GHS), \& ICF Macro. Ghana Demographic and Health Survey 2008. Accra: 2009.

17. Ghana Statistical Service (GSS), Ghana Health Service (GHS) and ICF Macro, Ghana Demographic and Health Survey 2014. Rockville: GSS, GHS, and ICF International; 2015. p. 153-8.

18. Manu, A. Sexual Communication Within Families And Influence On Sexual Behavior And Contraception Among Young People In The Brong Ahafo Region. University of Ghana, School of Public Health. Unpublished PhD Thesis. Accra: 2011.

19. Bilinsky P, Swindale A. Household dietary diversity score (HDDS) for measurement of household food access : indicator guide version 2 anne swindale household dietary diversity score (HDDS) for measurement of household food access : indicator guide version 2. 2006. http://www. fantaproject.org/sites/default/files/resources/HDDS_v2_Sep06_0.pdf. Accessed 15 Sept 2016.

20. WHO Child Growth Standards. Training course on child growth assessment. Geneva: WHO; 2008

21. WHO. Global Database on Child Growth and Malnutrition. WHO; 2015.

22. United Nations Division for Sustainable Development. CSD Indicators for Sustainable Development. 3rd Ed. Nutritional Status of Children. New York: United Nations Division for Sustainable Development; 2007. Retrieved: http://www.un.org/esa/sustdev/natlinfo/indicators/methodology_sheets/ health/nutritional_status.pdf. Accessed 9 Mar 2017.

23. Jayatissa $R$, Hossain $M$, and Nanayakkara $L$ (eds). Assessment of Nutritional Status and Associated Factors in Assessment of Nutritional Status and Associated Factors in Sri Lanka. Sri Lanka: Ministry Of Health, Sri Lanka. 2012.

24. Badake QD, Maina I, Mboganie MA, Muchemi G, Kihoro EM, Chelimo E. Nutritional status of children under five years and associated factors in Mbeere South District. J Rashid Latif Medical College. 2014;22:799-806.

25. Olack B, Burke H, Cosmas L, Bamrah S, Dooling K, Feikin DR, et al. Nutritional status of under-five children living in an informal urban settlement in Nairobi, Kenya. J Health Popul Nutr. 2011;29:357-63.

26. Yu SH, Mason J, Crum J, Cappa C, Hotchkiss DR. Differential effects of young maternal age on child growth. Glob Health Action. 2016;9:31171. https://doi. org/10.3402/gha.v9.31171.
27. Bandoh DA, Kenu E. Dietary diversity and nutritional adequacy of underfives in a fishing community in the central region of Ghana. BMC Nutr. 2017;3:2. https://doi.org/10.1186/s40795-016-0120-4.

28. Steyn NP, Bradshaw D, Norman R, Joubert JD, Schneider M, Steyn K. Dietary changes and the health transition in South Africa: implications for health policy. FAO technical report (2005). Cape town. Retrieved on: 20 February, 2018. From: http://www.fao.org/tempref/docrep/fao/009/a0442e/a0442e02.pdf.

\section{Ready to submit your research? Choose BMC and benefit from:}

- fast, convenient online submission

- thorough peer review by experienced researchers in your field

- rapid publication on acceptance

- support for research data, including large and complex data types

- gold Open Access which fosters wider collaboration and increased citations

- maximum visibility for your research: over $100 \mathrm{M}$ website views per year

At BMC, research is always in progress.

Learn more biomedcentral.com/submissions 